\title{
PENGARUH PAMDEMI COVID-19 TERHADAP ASPEK BELAJAR PADA PELAJAR SEKOLAH MENENGAH ATAS DI DKI-JAKARTA
}

\author{
James Julian $^{1 *}$, Fitri Wahyuni ${ }^{1}$, Achmad Zuchriadi P², Ferdyanto², Lomo MulaTua ${ }^{3}$ \\ ${ }^{1}$ Jurusan Teknik Mesin, Universitas Pembangunan Nasional Veteran Jakarta \\ Surel:juliansiregar@gmail.com \\ ${ }^{2}$ Jurusan Teknik Elektro, Universitas Pembangunan Nasional Veteran Jakarta \\ ${ }^{3}$ Jurusan Sistem Informasi, Universitas Pembangunan Nasional Veteran Jakarta
}

Masuk: 03-10-2020, revisi: 18-11-2020, diterima untuk diterbitkan: 07-03-2021

\begin{abstract}
ABSTRAK
Perubahan perilaku dan kebiasaan normal selama pandemi Covid-19 menjadi suatu tantangan tersendiri yang dihadapi oleh belahan dunia manapun. Perubahan kebiasaan secara mendadak tentu akan berdampak sangat signifikan terhadap beberapa kalangan seperti kalangan pelajar. Perubahan sistem belajar yang sebelumnya dilakukan secara luring dan berubah tiba-tiba secara daring tentu berdampak pada kesiapan pelajar dalam mempersiapkan diri mereka masing-masing. Penelitian ini bertujuan untuk mengkaji dampak perubahan dari kebiasaan belajar yang berubah dari sistem luring menjadi sistem daring secara kuantitatif dengan mengunakan kuisioner yang disebar ke seluruh wilayah ibukota Indonesia, yaitu DKI Jakarta. Semua penelitian ini dilakukan secara komprehensif dan masif guna mendapatkan data yang valid dan aktual. Beberapa metode analisis digunakan seperti uji validitas, uji ANOVA dan uji skala Likert yang berguna untuk (1) memastikan seluruh data dalam valitidas yang baik, (2) menganalisa dan menarik beberapa kesimpulan dari perubahan perilaku pelajar selama pandemi Covid-19 ini berlangsung. Dari hasil penelitian didapatkan bahwa pelajar yang tinggal di Ibukota Indonesia sebesar $47 \%$ sudah memahami bahaya pandemi Covid-19, sistem belajar daring yang telah dilakukan bisa menjadi kebiasaan baru sebanyak 54\%, masalah yang menjadi penghambat pelajar selama pandemi ini adalah Mager (malas gerak) sebesar 36\% dan sistem belajar yang paling diminati selama pandemi adalah belajar daring bersama-sama dengan guru sebesar $68 \%$.
\end{abstract}

Kata Kunci: Covid-19, kebiasaan baru, luring, daring, pelajar.

\begin{abstract}
Changes in behavior and normal habits during the Covid-19 pandemic are a challenge faced by any part of the world. A sudden change in habit will certainly have a very significant impact on some circles such as students. Changes in the learning system that were previously carried out offline and changed suddenly online certainly have an impact on the readiness of students to prepare themselves. This study aims to examine the impact of quantitative changes in learning habits from offline systems to online systems by using questionnaires distributed throughout the capital city of Indonesia, namely DKI Jakarta. All of these studies were carried out comprehensively and massively to obtain valid and actual data. Several analytical methods are used such as validity tests, ANOVA tests, and Likert scale tests which are useful for (1) ensuring all data is in good Validity, (2) analyzing and drawing some conclusions from changes in student behavior during the Covid-19 pandemic. From the results of the study, it was found that $47 \%$ of students living in the capital city of Indonesia already understand the dangers of the Covid-19 pandemic, the online learning system that has been carried out can become a new habit as much as 54\%, the problem that hinders students during this pandemic is Mager (lazy to move) by $36 \%$ and the most popular learning system during the pandemic was online learning together with teachers by $68 \%$. (2) analyze and draw some conclusions from changes in student behavior during the Covid-19 pandemic. From the results of the study, it was found that $47 \%$ of students living in the capital city of Indonesia already understand the dangers of the Covid-19 pandemic, the online learning system that has been carried out can become a new habit as much as 54\%, the problem that hinders students during this pandemic is Mager (lazy to move) by 36\% and the most popular learning system during the pandemic was online learning together with teachers by $68 \%$.
\end{abstract}

Keywords: Covid-19, new habits, offline, online, students. 


\section{PENDAHULUAN}

Fenomena pandemi Covid-19 atau yang awalnya biasa dikenal dengan virus corona memang sudah tidak bisa dipungkiri lagi menyebar hampir keseluruh belahan dunia, Badan Kesehatan Dunia (WHO) sendiri sudah sering dan banyak mempublikasikan laporan-laporan yang berkembang terhadap dampak yang terjadi akibat virus tersebut (Zhu, N., et al, 2020 dan Sohrabi, C., 2020). Beberapa bukti telah banyak menjelaskan dimana kasus Covid-19 merupakan jenis kasus pneumonia yang dapat menyebar dan berkembang dengan sangat cepat sehingga dapat dikatakan kedalam virus jenis baru. Virus jenis baru ini dikatakan memiliki basis yang sama secara mikro dengan virus yang telah beredar sebelumnya (Anderson, R. M.,et al, 2020).

Seperti yang telah kita ketahui bersama bahwa infeksi Covid-19 umumnya dideteksi sebagai gejala gangguan pernapasan akut seperti sesak napas, batuk dan deman tinggi (Holshue, M. L., 2020). Pada kasus yang dianggap khusus atau parah, Covid-19 secara langsung memberikan gejala pneumonia, gagal ginjal bahkan bisa berujung pada kematian. Secara umumnya kita bisa memastikan diri terbebas dari virus Covid-19 ini dengan cara inkubasi atau bisa disebut dengan isolasi diri dengan rata-rata adalah 5-6 hari, dengan durasi inkubasi terlama sebanyak 14 hari (Perlman, S., 2020).

Di Indonesia, pada awalnya kasus Covid-19 dikatakan masuk mulai pada bulan maret, 2020, dengan total pasien sebanyak 2 orang (Kementerian Kesehatan RI, 2020). Seiring dengan peningkatan waktu, kasus Covid-19 ini mulai melanda seluruh daerah Indonesia tak terkecuali Jakarta sebagai ibu kota negara. Sebenarnya peningkatan kasus covid-19 ini juga berlangsung dibeberapa negara, oleh karena itu WHO menetapkan Covid-19 sebagai pandemi dengan asumsi penyebaran yang cepat dan masif di berbagai belahan dunia (Cucinotta, D., \& Vanelli, M., 2020)

Dalam perkembangannya, pandemi ini memberikan dampak yang sangat singnifikan dalam perubahan gaya hidup atau pola hidup bermasyarakat. Sebagai contoh adalah budaya pengunaan masker yang sudah cukup efektif dan banyaknya gerakan-gerakan social dalam edukasi cuci tangan setiap atau setelah melakukan kegiatan. Semua itu dilakukan sebagai wujud pencegahan dini penyebaran Covid-19 (Kementerian Kesehatan RI, 2020 dan World Health Organization, 2020). Pola perubahan gaya hidup secara drastis tentu saja akan berdampak dalam sudut pandang social dan ekomoni. Terlebih lagi, karakter-karakter masyarakat Indonesia yang heterogen menyebabkan banyaknya kesalahan persepsi yang sering terjadi. Yang paling merasakan dan sangat memberatkan adalah kumpulan atau golongan masyarakat yang berada pada kirasan umur antara 17-20 tahun, dimana umur tersebut biasanya masuk dalam kategori remaja. Remaja dikatakan memiliki tingkat mobilitas dan frekuensi kontak yang sangat tinggi karena banyak melakukan interaksi dengan lingkungan sekitar (Aucejo, E. M., et al, 2020).

Lembaga-lembaga yang umumnya mengatur dan memfasilitasi para remaja ini adalah Kementerian Pendidikan dan Kebudayaan, tentu saja ada beberapa Kementerian lain terkait yang memiliki peran tersebut. Tetapi jika memandang pandemi ini sebagai suatu dampak yang besar, tentu Kementerian Pendidikan dan Kebudayaan menjadi sudut pandang yang unik dan lebih general dalam mengatur dan menjaga pertumbuhan para remaja ini. Beberapa kebijakan ditengah pandemi ini cukup banyak memberikan dampak yang signifikan bagi para remaja, khususnya bagi remaja yang sedang berencana mengikuti seleksi ujian masuk universitas. Banyak kendala-kendala yang coba diatasi Kementrian Pendidikan dan Kebudayaan ditengah pandemi Covid-19 ini seperti, mengatur sistem belajar daring yang efisien dan produktif. Penelitian ini bertujuan untuk mendapatkan informasi yang komprehensif secara kuantitatif antara pengaruh pandemi Covid-19 terhadap perubahan pola belajar para remaja yang berubah secara drastis selama berlakunya belajar daring. 


\title{
2. METODE PENELITIAN
}

\section{Area Studi}

Penelitian ini sepenuhnya dilakukan di wilayah Ibukota Republik Indonesia yaitu DKI Jakarta. Lebih spesifik lagi, wilayah yang menjadi target penelitian adalah sekolah-sekolah menengah atas yang terletak didalam batas wilayah DKI-Jakarta. Sekolah-sekolah tersebut dikelompokkan berdasarkan jenis sekolahnya, yaitu sekolah menengah atas tipe negeri dan sekolah menengah atas tipe swasta.

\section{Pengumpulan Data}

Data yang terkumpul merupakan hasil dari penyebaran kuesioner yang dilakukan pada periode minggu pertama bulan juni sampai minggu kedua bulan juni 2020. Durasi pengambilan data dilakukan selama 1 minggu penuh. Para responden adalah remaja-remaja yang berada pada tingkat XII atau tingkat akhir pada sekolah menengah atas. Remaja tingkat XII ini dipilih karena mempertimbangkan kebutuhan materi pelajaran yang harus mereka selesaikan sehingga urgensi akan belajar sangat dibutuhkan. Total responden adalah sebanyak 2000 responden dengan tersebar dalam 100 sekolah di DKI- Jakarta. 100 sekolah yang diambil sebagai sampel adalah sekolah yang mewakili wilayah DKI- Jakarta yaitu Jakarta Pusat, Jakarta Selatan, Jakarta Timur, Jakarta Barat dan Jakarta Utara. Sekolah menegah atas tersebut kemudian digolongkan menjadi dua jenis yaitu sekolah menegah atas tipe negeri dan sekolah menengah atas tipe swasta.

\section{Analisis Data}

Pada awalnya semua data yang terkumpul dilakukan uji valitidas. Uji validitas bertujuan untuk memastikan hubungan pertanyaan yang ditanyakan memiliki korelasi satu dengan yang lain (Messick, S., 1980 dan Wainer, H., \& Braun, H. I., 2013). Dari hasil uji validitas ini diharapkan dapat menarik kesimpulan dari kumpulan pertanyaan yang ditanyakan kepada responden. Persamaan validitas yang digunakan adalah:

$$
r=\frac{\sum\left[\left(x_{i}-\bar{x}\right)\left(y_{i}-\bar{y}\right)\right]}{\sqrt{\sum\left(x_{i}-\bar{x}\right)^{2} \cdot \sum\left(y_{i}-\bar{y}\right)^{2}}}
$$

\author{
Dimana, \\ $r$ adalah koefisien korelasi dari hubungan linier antara variabel $x$ dan $y$ \\ $x_{i}$ adalah nilai variabel $x$ dalam sampel \\ $y_{i}$ adalah nilai variabel $y$ dalam sampel \\ $\bar{x}$ adalah nilai rata-rata dari nilai variabel $x$ \\ $\bar{y}$ adalah nilai rata-rata dari nilai variabel $y$
}

Setelah hasil uji validitas didapatkan, maka kumpulan data tersebut dilanjutkan untuk dianalisis kembali dengan melakukan pengujian antara perbedaan dua atau lebih suatu kelompok data. Kelompok data tersebut dianalisis terhadap satu faktor atau variabel yang akan menjadi pertimbangan. Untuk menguji perbedaan tersebut digunakan metode Oneway Anova dengan mengunakan nilai signifikan $(\propto)$ adalah 0.05 (Bernhardson, C. S., 1975 dan Cuevas, A., Febrero, M., \& Fraiman, R., 2004).

Diakhir analisis akan dipergunakan medote skala Likert untuk mendapatkan hubungan variabel penelitian yang sebelumnya telah ditetapkan. Semuanya itu bertujuan untuk mendapatkan kesimpulan dari hasil 
kuesioner yang telah dikumpulkan. Hal ini perlu dilakukan untuk dapat memahami semua informasi yang telah didapatkan dan kemudian dianalisis menjadi satu kesatuan yang komprehensif dan valid (Joshi, A., Kale, S., Chandel, S., \& Pal, D. K., 2015 dan Vagias, W. M., 2006). Pengunaan skala Likert seperti yang ditunjukkan pada Tabel 1 berikut ini.

Tabel 1. Aturan Skala Likert

\begin{tabular}{cccccc}
$\Upsilon_{\text {Skala }}$ & Sangat tidak setuju & Tidak setuju & Cukup & Setuju & Sangat setuju \\
\hline
\end{tabular}

\section{HASIL DAN PEMBAHASAN}

Sistem pengumpulan data yang dilakukan adalah mengunakan kuesioner dengan alat bantu google form sebagai media pengumpulan data. Itu semua dilakukan untuk memastikan kuesioner ini tetap dapat dikirim ke responden dalam masa pandemi Covid-19 ini. Penyebaran dilakukan ke semua wilayah kota di DKI Jakarta. Total jumlah responden adalah sebanyak 2000 responden dengan menyebar merata disetiap wilayah kota sebanyak 400 responden untuk masing-masing wilayah kota. Dengan wilayah kota di DKI Jakarta sebanyak lima wilayah kota maka secara merata, wilayah kota mendapatkan jumlah yang sama untuk masing-masing sebesar $20 \%$ dari total keseluruhan responden, itu semua dapat dilihat seperti yang ditunjukkan pada Gambar 1.

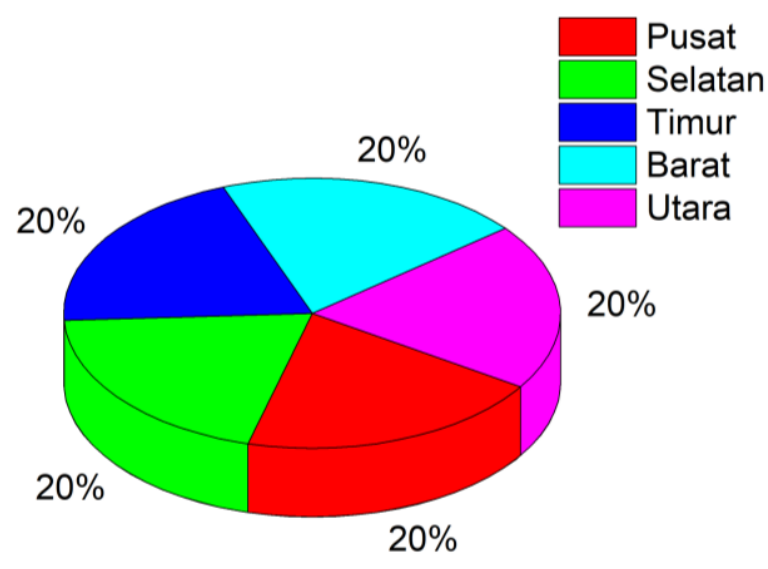

Gambar 1. Sebaran rata-rata responden di wilayah DKI Jakarta

Hasil data dari responden yang diperoleh kemudian dilakukan uji validitas. Uji validitas ini memiliki maksud dan tujuan untuk mendapatkan kejelasan hubungan pertanyaan sebagai nilai variabel yang telah disusun. Kemudian dilanjutkan dengan memastikan adanya korelasi pertanyaan yang terbentuk. Pada hasil uji validitas, nilar $r$ adalah sasaran yang harus didapatkan. Dimana nilai $r$ ini menunjukkan hubungan antara variabel-variabel yang tersusun memiliki hubungan linear atau tidak. Nilai $r$ yang diizinkan adalah $r$ harus mendekati sama dengan 1. Semakin nilai $r$ tersebut menuju sama dengan 1 maka nilai validitasnya dianggap terbaik.

Hasil uji validitas dapat ditunjukkan pada Tabel 2. Disana dapat dilihat dengan jelas bahwa nilai validitas pertanyaan yang dibentuk menunjukkan nilai yang cukup bervariasi. Akan tetapi jika diperhatikan lebih teliti, nilai $r$ tersebut menunjukkan nilai validitas yang baik. Itu semua karena nilai $r$ yang didapat sudah menunjukkan kedekatan nilai yang nilainya hampir sama dengan 1 . 
Tabel 2. Hasil uji validitas

\begin{tabular}{cccc}
\hline & 1 & 2 & 3 \\
\hline Pertanyaan 1 & -- & & \\
\hline Pertanyaan 2 & 0.86573 & -- & -- \\
\hline Pertanyaan 3 & 0.901294 & 0.818339 & \\
\hline
\end{tabular}

Kuesioner yang diberikan kepada responden berisi beberapa pertanyaan yang telah disusun sedemikian rupa. Itu semua bertujuan untuk dapat memahami situasi responden yang dianggap merupakan perwakilan atau sampel dari populasi di DKI Jakarta. Kumpulan pertanyan secara spesifik berisikan hal-hal yang dapat menggali konsidi responden seperti sebagai berikut:

a. Menurut anda, bagaimana proses pemahaman anda tentang segala informasi terkait Covid19 yang anda ketahui

b. Menurut anda, bagaimana sehari-hari anda menjalani kegiatan belajar dirumah (online) selama periode Covid-19

c. Menurut anda, apakah masalah yang paling sulit diatasi selama kegiatan belajar jarak jauh (online)

d. Menurut anda, sistem belajar apa yang paling anda sukai dan membuat anda tertarik untuk belajar

Kumpulan data hasil pertanyaan tersebut kemudian diolah untuk mendapatkan petunjuk terhadap fenomena yang terjadi. Setiap data diklasifikasikan berdasarkan jawaban responden untuk dapat mengetahui sebaran variasi jawaban responden. Berikut ini hasil pengolahan data untuk melihat jawaban responden diseluruh wilayah DKI Jakarta, seperti yang ditampilkan pada Gambar 2.

Analisis dilakukan kembali, dengan mengkategorikan variasi data untuk masing- masing sekolah menengah atas tipe negeri dan sekolah menengah atas tipe swasta. Analisis ini perlu dilakukan dengan pertimbangan kemiripan kondisi yang dihadapi yaitu kondisi pandemi Covid-19. Tentu saja menampilkan variasi data untuk sekolah menengah atas tipe negeri dan sekolah menengah atas tipe swasta ini, bisa dianggap premature karena lingkungan hidup atau gaya hidup remaja yang bersekolah di sekolah negeri tentu sangat berbeda dengan kehidupan di sekolah swasta. Akan tetapi, dalam beberapa sudut pandang bisa dianggap relevan jika kita memandang pandemi ini sebagai fenomena yang global. Dalam arti semua kalangan baik itu sekolah negeri atau sekolah swasta juga berdampak signifikan dalam rutinitas seharihari. 

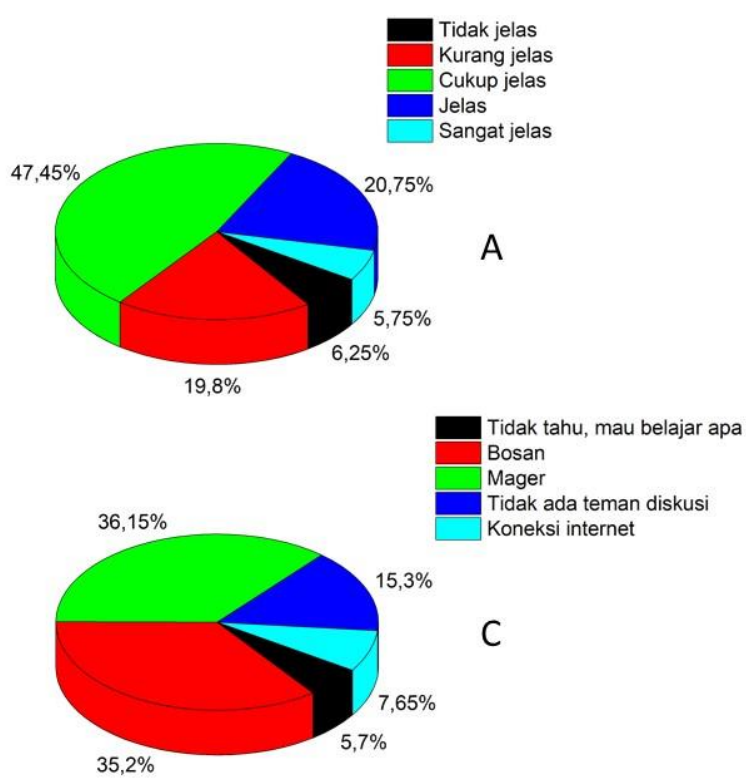

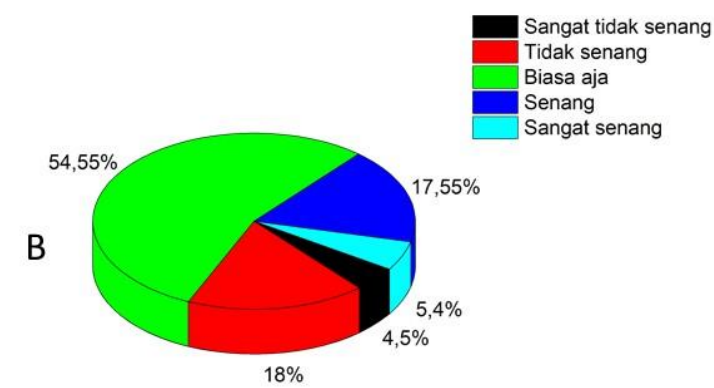

Belajar lewat video Youtube Belajar latihan soal sendiri Belajar online bersama teman-teman Ikut kelas online baik dengan guru atau online lainnya
Inelaj $68,75 \%$

D

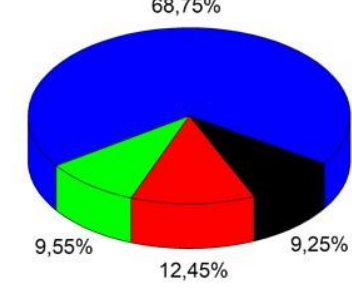

Gambar 2. Variasi pendapat responden di wilayah Jakarta (A) Pertanyaan 1, (B) Pertanyaan 2, (C) Pertanyaan 3, (D) Pertanyaan 4.

Dampak signifikan dari pandemi Covid-19 bagi kalangan pendidikan adalah berubahnya pola belajar yang awalnya dilakukan secara luring dan terpaksa dilakukan secara daring. Tentu saja perubahan pola yang terjadi secara mendadak ini akan berdampak pada kualitas dan kuantitas siswa dalam belajar. Kesiapan instrument belajar daring mungkin bukan masalah berarti bagi pelajar yang tinggal di ibu kota. Karena pelajar yang tinggal di ibu kota umumnya sudah tergolong dalam keluarga yang cukup mapan. Walaupun ada segelintir pelajar yang dianggap kurang mampu tetapi pihak sekolah dan Kementerian Pendidikan dan Kebudayaan telah bersinergi dengan baik dalam mengatasi problema ini.

Untuk dapat memahami variasi hasil pendapat responden dapat dilihat pada Gambar 3. Pada Gambar 3 untuk 3A dan 3B adalah pendapat responden untuk pertanyaan 1. Gambar 3C dan 3D adalah pendapat responden untuk pertanyaan 2. Gambar $3 \mathrm{G}$ dan $3 \mathrm{H}$ adalah pendapat responden untuk pertanyaan 4 . Gambar 3E dan 3F adalah pendapat responden untuk pertanyaan 3. Selain itu, terdapat kode STS yang melambangkan jawaban untuk sangat tidak senang untuk Gambar 3C dan 3D. Kemudian untuk Gambar 3G dan 3H, untuk kode A1 melambangkan jawaban responden memilih belajar lewat video youtube, A2 untuk belajar sendiri, A3 untuk online bersama teman-teman dan A4 untuk belajar bersama guru sekolah atau guru les secara online. 

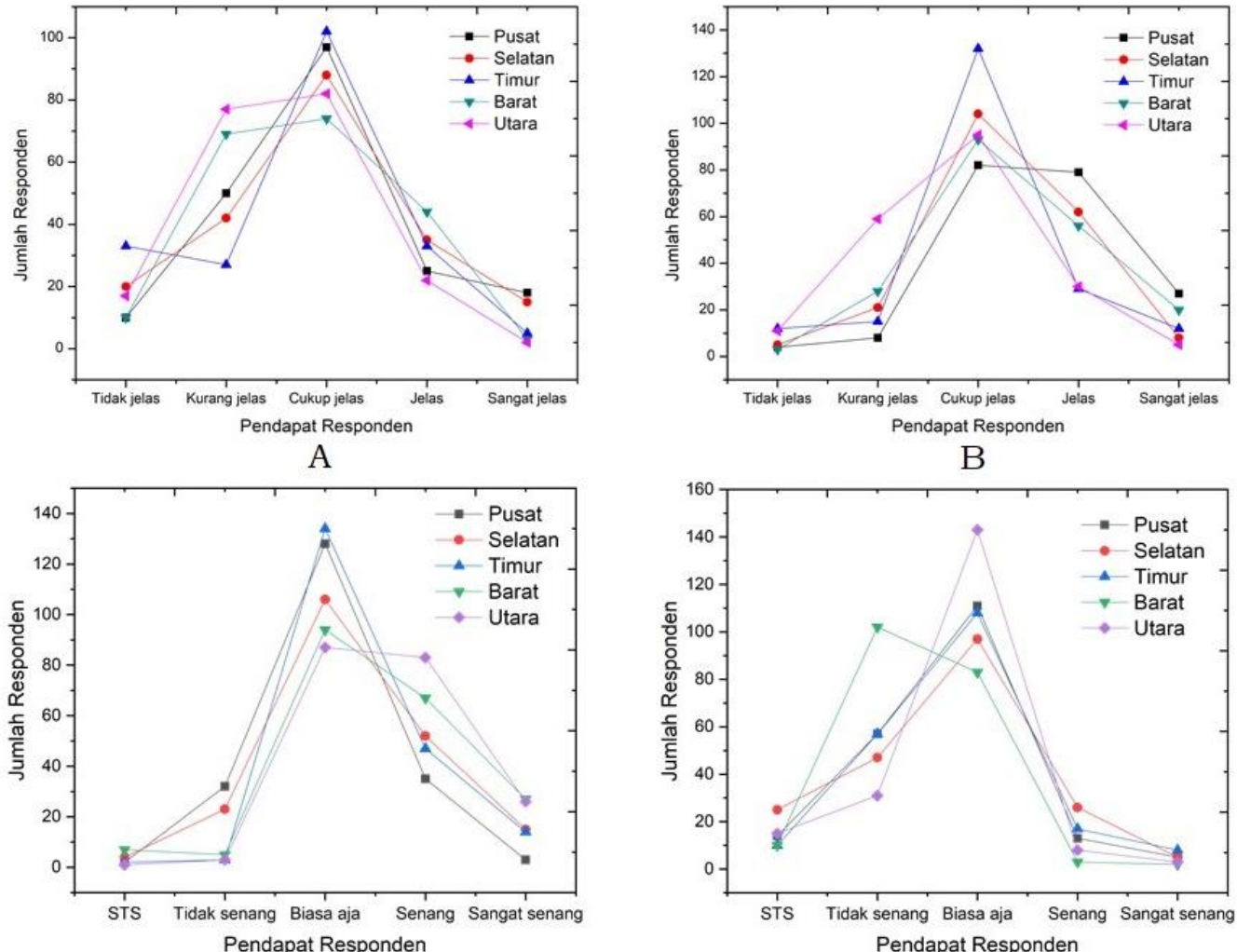

$\mathrm{B}$

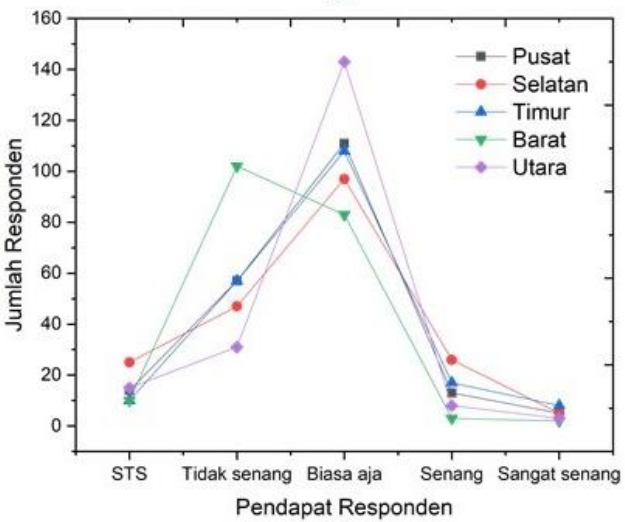

$\mathrm{D}$
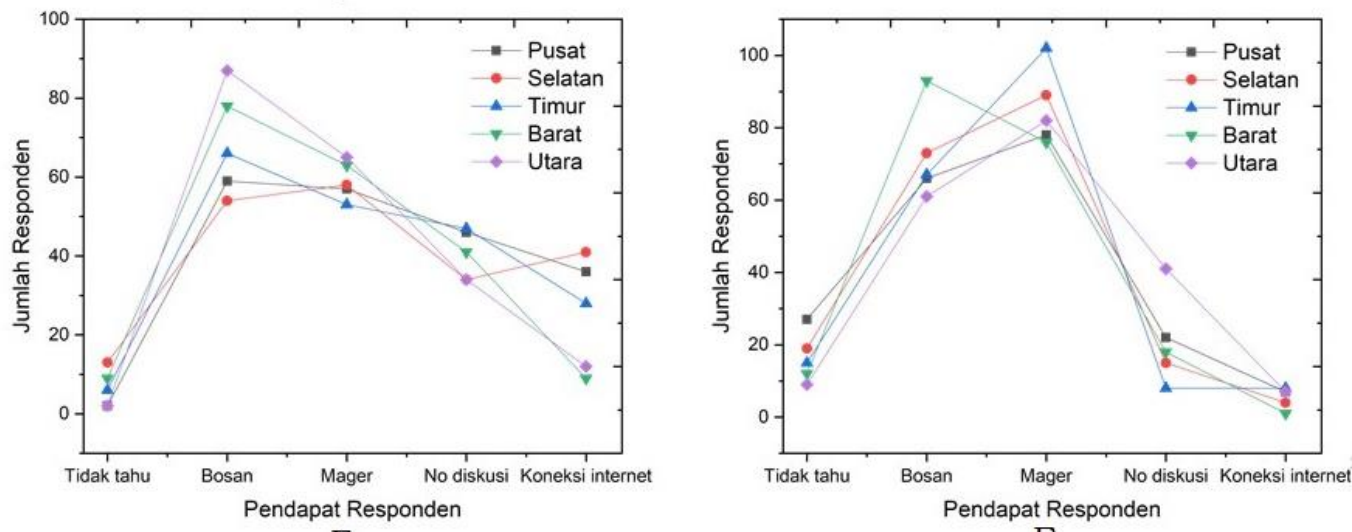

$\mathrm{E}$

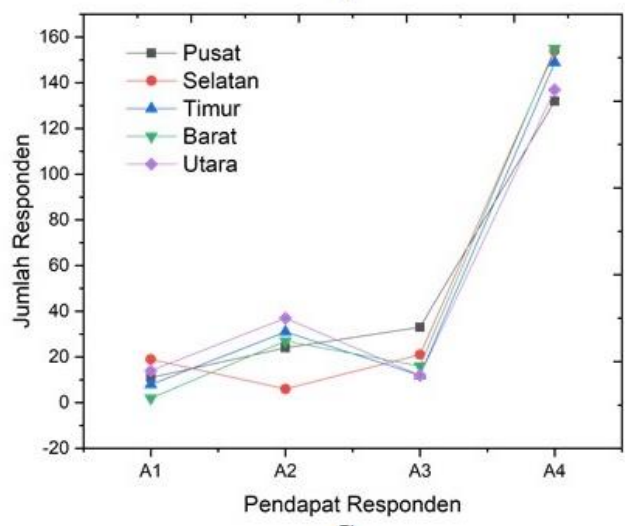

G

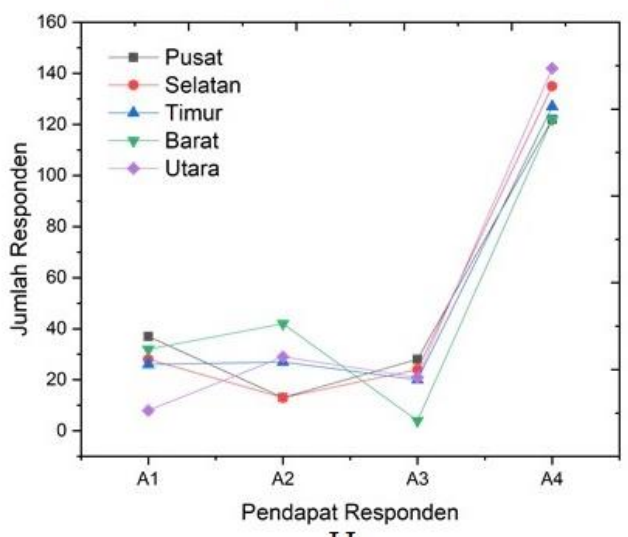

$\mathrm{H}$

Gambar 3. Pendapat responden dari 4 pertanyaan dan kategori sekolah secara berurutan masing-masing negeri (A), (C), (E), (G) dan swasta (B), (D), (F), (H) 
Hasil variasi responden berdasarkan kategori sekolah menegah atas tipe negeri dan sekolah menegah atas tipe swasta kemudian dianalisis kembali dalam uji ANOVA. Uji ANOVA ini dilakukan untuk mencari kemiripan jawaban secara rata-rata dari jawaban yang telah diperoleh berdasarkan jenis sekolahnya. Hasil dalam uji ANOVA dapat ditunjukkan pada Gambar 4. Di sana bisa kita tarik beberapa kesimpulan dimana, banyak beberapa nilai P-value yang berada tepat diatas garis signifikan $(\propto)$ atau P-value $>\propto$.

Hasil P-value yag berada diatas garis signifikan berarti bahwa secara nilai rata-rata pendapat pelajar sekolah menegah atas tipe negeri dan sekolah menegah atas tipe swasta memiliki kemiripan pendapat. Sedangkan untuk nilai P-value yang berada tepat di bawah garis signifikan, P-value $\leq \propto$ menunjukkan arti secara nilai rata-rata keseluruhan jawaban yang dipilih oleh pelajar sekolah menegah atas tipe negeri dan sekolah menegah atas tipe swasta tidak memiliki kemiripan atau paling tidak ada 1 sekolah di wilayah kota tertentu memiliki pendapat yang sangat berbeda dengan wilayah kota lainnya.

Untuk lebih mudah memahami hasil dari uji ANOVA ini bisa dilihat secara menyeluruh pada Tabel 3. Dimana ditabel tersebut dipaparkan lebih didetail untuk setiap wilayah kota. Nilai H0 dan H1 masing masing adalah sebagai berikut:

a. H0 adalah keseluruhan nilai rata-rata disatu daerah tersebut baik itu sekolah menegah atas tipe negeri dan sekolah menegah atas tipe swasta dianggap sama $\mu_{1}=\mu_{2}$.

b. H1 adalah keseluruahn nilai rata-rata disatu daerah tersebut baik itu sekolah menegah atas tipe negeri dan sekolah menegah atas tipe swasta dianggap paling sedikit ada satu sekolah yang memiliki rata-rata yang berbeda signifikan $\mu_{1} \neq \mu_{2}$.

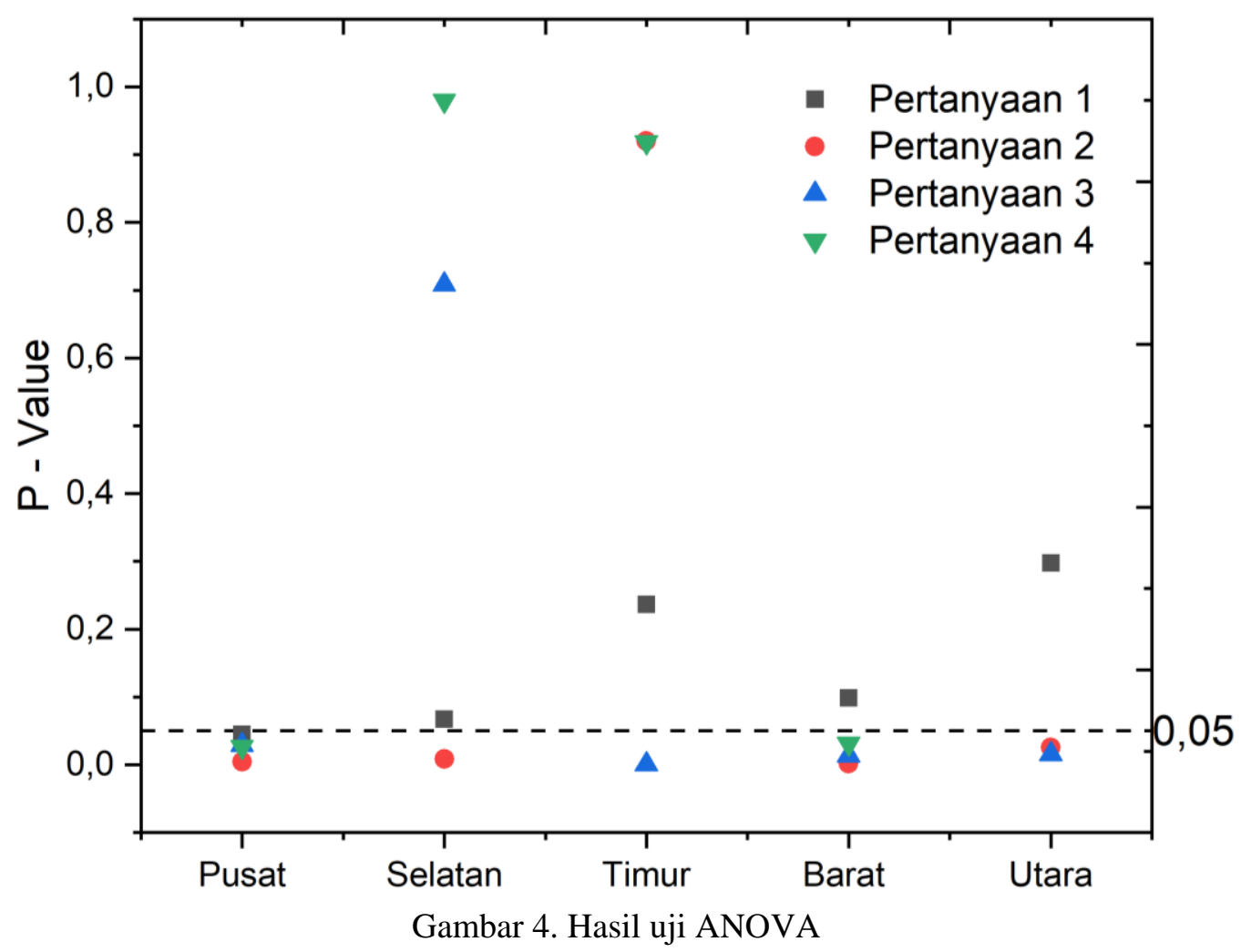

Jika merujuk pada pengertian H0 dan H1 maka, pada pertanyaan 1 dan 4 pada Tabel 3 dapat disimpulkan secara keseluruhan ada wilayah yang memiliki jawaban responden yang sama. Itu berarti bisa dikatakan 
pelajar disana baik itu sekolah menegah atas tipe negeri dan sekolah menegah atas tipe swasta memiliki kemiripan kondisi secara kuantitatif. Tetapi khusus untuk wilayah Jakarta pusat baik itu sekolah menegah atas tipe negeri dan sekolah menegah atas tipe swasta memiliki perbedaan pendapat. Sehingga bisa dikatakan kondisi mereka tidak sama atau mirip sepenuhnya.

Sedangkan untuk pertanyaan 2 dan pertanyaan 3 dari hasil uji ANOVA ini dikatakan hampir seluruhnya rata-rata pendapat responden memiliki perbedaan yang cukup signifikan kecuali untuk wilayah Jakarta Timur dan Jakarta Selatan masing-masing untuk pertanyaan 2 dan 3.

Tabel 3. Kesimpulan uji ANOVA

\begin{tabular}{ccccc}
\hline \multicolumn{5}{c}{ Anova Test } \\
\hline Wilayah & Pertanyaan 1 & Pertanyaan 2 & Pertanyaan 3 & Pertanyaan 4 \\
\hline Pusat & $\mathrm{H} 1$ & $\mathrm{H} 1$ & $\mathrm{H} 1$ & $\mathrm{H} 1$ \\
\hline Selatan & $\mathrm{H} 0$ & $\mathrm{H} 1$ & $\mathrm{H} 0$ & $\mathrm{H} 0$ \\
\hline Timur & $\mathrm{H} 0$ & $\mathrm{H} 0$ & $\mathrm{H} 1$ & $\mathrm{H} 0$ \\
\hline Barat & $\mathrm{H} 0$ & $\mathrm{H} 1$ & $\mathrm{H} 1$ & $\mathrm{H} 0$ \\
\hline Utara & $\mathrm{H} 0$ & $\mathrm{H} 1$ & $\mathrm{H} 1$ & -- \\
\hline
\end{tabular}

Tabel 4. Hasil analisis skala Likert untuk pertanyaan 1 dan 2

\begin{tabular}{ccccccc}
\hline & Pertanyaan 1 & Kesimpulan & Pertanyaan 2 & Kesimpulan & Rata-rata & Kesimpulan \\
\hline Pusat N & 591 & Cukup & 605 & Cukup & 598 & Cukup \\
\hline Pusat S & 717 & Jelas & 538 & Cukup & 627,5 & Cukup \\
\hline Selatan N & 583 & Cukup & 651 & Cukup & 617 & Cukup \\
\hline Selatan S & 647 & Cukup & 539 & Cukup & 593 & Cukup \\
\hline Timur N & 550 & Cukup & 668 & Cukup & 609 & Cukup \\
\hline Timus S & 614 & Cukup & 556 & Cukup & 585 & Cukup \\
\hline Barat N & 561 & Cukup & 702 & Jelas & 631,5 & Cukup \\
\hline Barat S & 662 & Cukup & 485 & Kurang & 573,5 & Cukup \\
\hline Utara N & 515 & Cukup & 730 & Jelas & 622,5 & Cukup \\
\hline Utara S & 559 & Cukup & 553 & Cukup & 556 & Cukup \\
\hline
\end{tabular}

Analisis terakhir adalah mengunakan skala Likert untuk mencari tahu kesimpulan pendapat secara ratarata untuk setiap wilayah dan kategori sekolah menegah atas tipe negeri dan sekolah menegah atas tipe swasta. Hasil uji skala Likert dapat ditunjukkan pada Tabel 4, Tabel 5 dan Tabel 6. Secara keseluruhan uji Likert menunjukkan hasil yang sangat memuaskan dari penelitian yang telah dilakukan ini. Seperti contohnya pada Tabel 4, disana dikatakan secara rata-rata pelajar disana cukup mengetahui informasi tentang bahaya pandemi Covid-19 ini. Kemudian untuk pertanyaan 2 disana disimpulkan pelajar merasakan perasaan yang biasa-biasa saja dalam kegiatan belajar daring. Hasil ini mungkin dianggap cukup aneh karena seharusnya pelajar merasakan hal-hal yang kurang berkenan dalam proses belajar daring. Akan tetapi hasil didapat menunjukkan perilaku yang biasa-biasa saja. Itu karena ketika pengambilan data, proses kegiatan belajar online sudah berlangsung kira- kira 2 bulan lamanya. Oleh karena itu hasil ini bisa dikatakan valid karena pelajar sekolah menegah atas tipe negeri dan sekolah menegah atas tipe swasta sudah mulai terbiasa dalam belajar secara daring dimasa pandemi Covid-19 ini. 
Untuk Tabel 5 dapat disimpulkkan bahwa selama masa pendemi Covid-19 berlangsung. Kegiatan belajar daring yang terpaksa dijalankan, jika dilihat secara rata-rata maka masalah yang umumnya timbul oleh pelajar baik itu dari sekolah menegah atas tipe negeri dan sekolah menegah atas tipe swasta adalah rasa mager (malas gerak). Pendapat ini timbul dikarenakan durasi belajar online yang lama, menyebabkan pelajar jadi kurang suka beraktifitas lain dan cenderung pasif.

Tabel 5. Hasil analisis skala Likert untuk pertanyaan 3

\begin{tabular}{ccccccc}
\hline & Negeri & Kesimpulan & Swasta & Kesimpulan & Rata-rata & Kesimpulan \\
\hline Pusat & 655 & Mager & 516 & Bosan & 585,5 & Mager \\
\hline Selatan & 636 & Mager & 512 & Bosan & 574 & Mager \\
\hline Timur & 625 & Mager & 527 & Mager & 576 & Mager \\
\hline Barat & 563 & Mager & 503 & Bosan & 533 & Mager \\
\hline Utara & 567 & Mager & 576 & Mager & 571,5 & Mager \\
\hline
\end{tabular}

Sedangkan untuk hasil uji skala Likert pada pertanyaan 4 seperti yang ditunjukkan Tabel 4. Dikatakan pelajar, baik itu dari sekolah menegah atas tipe negeri dan sekolah menegah atas tipe swasta secara ratarata lebih memilih tetap melakukan belajar secara daring dari pada sistem belajar yang lainnya. Ini bisa dikatakan lumrah terjadi karena pola belajar sebelum pandemi Covid-19 di Indonesia ini masih umumnya bersifat konvensional sehingga pertemuan dengan guru dianggap menjadi suatu kebiasaan yang wajib.

Tabel 6. Hasil analisis skala Likert untuk pertanyaan 4

\begin{tabular}{ccccccc}
\hline Pusat & Negeri & Kesimpulan & Swasta & Kesimpulan & Rata-rata & Kesimpulan \\
\hline Selatan & 710 & $\begin{array}{c}\text { Ikut kelas } \\
\text { online } \\
\text { online }\end{array}$ & 635 & $\begin{array}{c}\text { online bersama } \\
\text { teman-teman }\end{array}$ & 660,5 & Ikut kelas online \\
\hline Timur & 702 & $\begin{array}{c}\text { Ikut kelas } \\
\text { online }\end{array}$ & 648 & $\begin{array}{c}\text { Ikut kelas online } \\
\text { online bersama } \\
\text { teman-teman }\end{array}$ & 688 & Ikut kelas online \\
\hline Barat & 724 & $\begin{array}{c}\text { Ikut kelas } \\
\text { online }\end{array}$ & 616 & $\begin{array}{c}\text { online bersama } \\
\text { teman-teman }\end{array}$ & 670 & Ikut kelas online \\
\hline Utara & 672 & $\begin{array}{c}\text { Ikut kelas } \\
\text { online }\end{array}$ & 697 & Ikut kelas online & 684,5 & Ikut kelas online \\
\hline
\end{tabular}

\section{KESIMPULAN}

Dari beberapa hasil analisis yang telah dilakukan maka diambil kesimpulan antara lain:

a. Uji validitas dalam hasil responden menunjukkan hasil yang baik, dengan demikian data hasil responden dapat dikatakan valid.

b. Uji ANOVA menunjukkan untuk beberapa pertanyaan yang diberikan kepada responden mendapatkan hasil yang bisa dikatakan cukup memiliki kemiripan. Walaupun beberapa hasil menolak H0 tetapi hampir seragam menunjukkan kesamaan pada hasil H1 begitu juga sebaliknya.

c. Uji skala Likert dapat memberikan kesimpulan yang menyeluruh dari peneliti yang telah dilakukan seperti: 
- Sepenuhnya pelajar baik itu dari sekolah menegah atas tipe negeri dan sekolah menegah atas tipe swasta sudah memahami bahaya pandemi Covid-19 sebesar $47 \%$

- Kegiatan belajar daring yang dilakukan selama pandemi Covid-19 dirasakan biasa-biasa saja bagi pelajar sebesar 54\%. Ini menunjukkan bahwa pelajar telah membiasakan diri dan mempersiapkan diri dengan baik selama proses belajar daring.

- Masalah utama pelajar yang tinggal di ibukota adalah Mager sebesar 36\% yaitu malas beraktifitas lebih. Itu muncul karena kebiasaan yang cukup lama berada didalam rumah terus menerus, sehingga animo untuk melakukan kegiatan lain menjadi tidak terbentuk.

- Sistem belajar yang berbasis online atau daring dengan guru menjadi sistem belajar yang paling diminati sebesar 68\%. Karena dianggap cukup bisa memberikan interaksi dan umpan balik dari pada sistem lain seperti belajar sendiri atau belajar online dengan teman-teman.

d. Secara keseluruhan, pengaruh pandemi Covid-19 terhadap perubahan pola belajar yang berubah secara drastis sehingga menyebabkan berlakunya sistem belajar daring oleh para pelajar dikatakan cukup berdampak signifikan. Akan tetapi seiring dengan perjalanan waktu, para pelajar dapat beradaptasi dengan baik terutama dapat membiasakan diri dari sistem belajar daring yang dilakukan selama pandemi Covid-19 ini berlangsung.

\section{REFERENSI}

Anderson, R. M., Heesterbeek, H., Klinkenberg, D., \& Hollingsworth, T. D. (2020). How will country-based mitigation measures influence the course of the COVID-19 epidemic?. The Lancet, 395(10228), 931-934.

Aucejo, E. M., French, J., Araya, M. P. U., \& Zafar, B. (2020). The impact of COVID-19 on student experiences and expectations: Evidence from a survey. Journal of Public Economics, 104271.

Bernhardson, C. S. (1975). 375: Type I error rates when multiple comparison procedures follow a significant $\mathrm{F}$ test of ANOVA. Biometrics, 229-232.

Cucinotta, D., \& Vanelli, M. (2020). WHO declares COVID-19 a pandemic. Acta bio-medica: Atenei Parmensis, 91(1), 157-160.

Cuevas, A., Febrero, M., \& Fraiman, R. (2004). An anova test for functional data. Computational statistics \& data analysis, 47(1), 111-122.

Holshue, M. L., DeBolt, C., Lindquist, S., Lofy, K. H., Wiesman, J., Bruce, H., ... \& Diaz, G. (2020). First case of 2019 novel coronavirus in the United States. New England Journal of Medicine.

Joshi, A., Kale, S., Chandel, S., \& Pal, D. K. (2015). Likert scale: Explored and explained. Current Journal of Applied Science and Technology, 396-403.

Kementerian Kesehatan RI Direktorat Jenderal Pencegahan dan Pengendalian Penyakit (P2P). (2020). Pengendalian Coronavirus Disease (Covid19). Revisi ketiga Pedoman Kesiapsiagaan Menghadapi Coronavirus Disease (COVID-19).

Messick, S. (1980). Test validity and the ethics of assessment. American psychologist, 35(11), 1012.

Perlman, S. (2020). Another decade, another coronavirus. Mass Medical Soc. 
Sohrabi, C., Alsafi, Z., O’Neill, N., Khan, M., Kerwan, A., Al-Jabir, A., ... \& Agha, R. (2020). World Health Organization declares global emergency: A review of the 2019 novel coronavirus (COVID-19). International Journal of Surgery.

Vagias, W. M. (2006). Likert-type scale response anchors. Clemson International Institute for Tourism \& Research Development, Department of Parks, Recreation and Tourism Management. Clemson University.

Wainer, H., \& Braun, H. I. (Eds.). (2013). Test validity. Routledge.

World Health Organization. (2020). Rational use of personal protective equipment (PPE) for coronavirus disease (COVID-19): interim guidance, 19 March 2020 (No. WHO/2019nCoV/IPC PPE_use/2020.2). World Health Organization.

Zhu, N., Zhang, D., Wang, W., Li, X., Yang, B., Song, J., ... \& Niu, P. (2020). A novel coronavirus from patients with pneumonia in China, 2019. New England Journal of Medicine. 